\title{
Hemoglobin Kansas found by electrophoretic diagnosis in Brazil
}

\author{
Claudia R. Bonini-Domingos \\ Patrícia H.O. Calderan ${ }^{2}$ \\ Fátima A.M. Siqueira ${ }^{1}$ \\ Paulo C. Naoum ${ }^{1}$
}

\begin{abstract}
Some hemoglobin variants with abnormal oxygen affinity have been reported so far from various regions of the world. They can be classified by their oxygen affinity and 15 variants with low oxygen affinity have been reported. A number of hemoglobin mutants which show an abnormal affinity for oxygen have been reported, but only few cases of hemoglobin Kansas. All cases reported so far are from Japan or in Japanese families. In this paper we describe a Brazilian patient with cyanosis and bemoglobin Kansas diagnosed by an electrophoretical procedure.

Rev.bras.hematol.hemoter.,2002,24(1):37-39
\end{abstract}

Keywords: Hemoglobin Kansas, electrophoretic diagnosis, abnormal hemoglobins

\section{Introduction}

Hemoglobin Kansas is characterized by an unusual low oxygen affinity. Since this is the major cause of cyanosis in carriers, it is of interest that dark blood samples containing hemoglobin Kansas turn almost red after vigorous shaking with air, in contrast to the dark brown color which remains in the case of methaemoglobinaemia or the hemoglobin $M$ disease (1).

Hemoglobin Kansas is also characterized by tendency for subunit dissociation, autooxidation and heat liability. It differs from normal hemoglobin in its equilibrium with oxygen, its tendency to dissociate into subunits and its chromatographic behavior. These differences appear to be associated with a single neutral substitution in the $\beta$ chain $[\beta 102$ (G4) Asn $\rightarrow$ Thr]. This is a residue in the internal interface with heme and alpha- 1 beta- 2 contact. In the heterozygosity the hematology is normal $(2,3)$.

More than 50 Hemoglobin variants with abnormal oxygen affinity have been reported so far from various regions of the world (4). Hemoglobin Kansas is a variant $\mathrm{Hb}$ with low oxygen affinity. The structure-function relationship of this hemoglobin has been studied in detail (5). Residue G4 appears to be oriented "inward" into the heme, and the group with which it makes contact is not yet known $(6,7)$.

\section{Case report}

The proposita is a 21 year-old Caucasian woman from Cuiabá, MT, with cyanosis and hematological values as follows: RBC count $5.6 \times 10^{6} / \mathrm{mm}^{3}$; Hemoglobin $18.3 \mathrm{~g} / \mathrm{dl}$; Hematocrit

1- Laboratório de Hemoglobinas, Departamento de Biologia, IBILCE-UNESP, São José do Rio Preto, SP

2 - Laboratório de Hematologia, Faculdade de Farmácia, UNIC, Cuiabá, MT

Correspondence to: Cláudia R. Bonini-Domingos

IBILCE-UNESP, Departamento de Biologia, Laboratório de Hemoglobinas. Rua Cristóvão Colombo, 2265. 15054-000.

São José do Rio Preto. SP. Brasil. Fax: 55 (17) 221-2390 • E-mail: bonini@bio.ibilce.unesp.br 
$53 \%$; WBC count $9,300 / \mathrm{mm}^{3}$; platelet count 205,000; red cell morphology normal, mean corpuscular volume 94.5/fl; mean corpuscular hemoglobin concentration $34.5 \mathrm{~g} / \mathrm{dl}$.

She had been healthy with no suggestions of illnesses compatible with heart or blood disease. Physical examination was negative except for cyanotic lips. An electrocardiogram and an echocardiogram gave normal results. The liver, spleen and kidneys were not palpable.

A sample of arterial blood obtained while the patient was undergoing oxygen inhalation therapy, was very dark with partial oxygen pressure $\left(\mathrm{PO}_{2}\right)$ at $102.40 \mathrm{~mm} \mathrm{Hg}$, partial carbon dioxide pressure $\left(\mathrm{PCO}_{2}\right)$ at $31.80 \mathrm{~mm} \mathrm{Hg}$ and $\mathrm{pH} 7.39$.

In cellulose acetate electrophoresis at alkaline $\mathrm{pH}$ (8), the sample hemolysate showed an abnormal band with mobility like $\mathrm{Hb}$ F. Quantification by densitometry was 38.4\%. In acid $\mathrm{pH}$ electrophoresis the sample showed an $\mathrm{Hb}$ A pattern.

The abnormal component was also found in agarose gel plate isoelectric-focusing (9), between $\mathrm{Hb} \mathrm{A}$ and F. Globin chain electrophoresis at 8.6 $\mathrm{pH}$ showed a band for the beta mutant position. The isopropanol test was normal and somewhat unstable in relation to heat denaturation.

It was impossible to make a familiar study in this case. According to these results, the patient's hemoglobin appeared to be heat labile, have a low heme-heme interaction and low oxygen affinity.

\section{Discussion}

Hb Kansas was reported by Reissmann et al and also by Ishiguro et al in 1983 in Japan. Until 1992 only three cases were reported in the world (4).

More than 50 hemoglobin variants with abnormal oxygen affinity have been reported so far from various regions of the world. They can be classified by their affinity for oxygen, and 15 variants with low oxygen affinity have been reported including $\mathrm{Hb}$ Kansas. The structure-function relationships of $\mathrm{Hb}$ Kansas have been studied in detail (6).

Stability of normal adult hemoglobin depends upon the maintenance of the satisfactory spatial relationship between the two alpha and two beta chains. Amino acid substitutions may weaken the links that hold the tetramer together. Hemoglobin Kansas has an amino acid substitution, $\beta$ 102(G4)Asn>Thr, which weakens the contacts along the $\alpha 1 \beta 2$ interface. The main clinical feature of this abnormal hemoglobin is, however, not an instability but a very low oxygen affinity. Because of the great quantity of circulating reduced hemoglobin cyanotic carriers of hemoglobin Kansas were originally thought to have methaemoglobinaemia. Hemoglobin Kansas is associated with no clinical abnormalities other than cyanosis.

It is noteworthy that in this case the patient had slight cyanosis and characteristic hematological data. The electrophoretic results and hematological data allowed us to conclude that the proposita was a carrier of hemoglobin Kansas.

\section{Hemoglobina Kansas diagnosticada através de eletroforese no Brasil}

Cláudia R. Bonini-Domingos, Patrícia H.O. Calderan, Fátima A.M. Siqueira, Paulo C. Naoum

\section{Resumo}

Hemoglobinas variantes com afinidade anormal ao oxigênio têm sido encontradas em várias partes do mundo. Pela sua afinidade ao oxigênio, estas hemoglobinas variantes têm sido classificadas e 15 variantes com baixa afinidade relatadas. Numerosas hemoglobinas mutantes com afinidade anormal têm também sido relatadas, mas somente poucos casos de Hemoglobina Kansas. Os casos são de pacientes procedentes do Japão, ou de famílias com descendentes japoneses. Neste relato descrevemos um paciente com manifestações de cianose que teve o seu diagnóstico confirmado através da eletroforese.

Rev.bras.hematol.hemoter.,2002,24(1):37-39

Palavras-chave: Hemoglobina Kansas, eletroforese, hemoglobinas anormais 


\section{References}

1. Reissmann KR, Ruth WE \& Nomura T. A Human hemoglobin with lowered oxygen affinity and impaired beme-beme interactions. Journal of clinical investigation. 1961. 40:1826-1833.

2. Schmidt RM. Editor. Abnormal haemoglobins and thalassemia - Diagnostic aspects. Academic Press. 1975. New York. p.366

3. Lehmann H \& Huntsman RG. Man's Haemoglobins. North Holland Publishing Company. 1974. p.226

4. Morita K, Fukuzawa J, Onodura S, Kawamura Y, Sasaki N, Fujisawa K, Ohba $\mathrm{Y}$, Miyaji T, Hayashi $\mathrm{Y}$ \& Yamazaki N. Hemoglobin Kansas found in a patient with polycytemia. Annals of Hematology, 1992. 65:229-231.

5. Ishiguro K, Ohba $\mathrm{Y}$, Hattori $\mathrm{Y}$, Miyaji T, Oshida Y, Tachinami T, Takabatake S \& Nakaizumi K. Hemoglobin Kansas in a
Japanese family. Hemoglobin, 1983. 7(6): 573-579.

6. Bonaventura J \& Riggs A. Hemoglobin Kansas, a Human bemoglobin with a neutral amino acid substitution and an abnormal oxygen equilibrium. The Journal of Biological Chemistry, 1968. 243(5): 980991.

7. Gibbons QH. Kinetic and equilibrium properties of hemoglobin Kansas. The Journal of Biological Chemistry, 1973. 248(17): 5976-5986.

8. Dacie JV \& Lewis SM. Practical Haematology. $8^{\text {th }}$ edition. 1995. Churchill Livingstone. Edinburgh.

9. Naoum PC. $2^{\mathrm{a}}$ edição. Eletroforeses Técnicas e diagnóstico. 1999. Editora Santos, São Paulo, Brasil.

Recebido: 17/07/01

Aceito: 13/02/02 